\begin{tabular}{lcr}
\hline & ANNALES & \\
& & \\
UNIVERSITATIS MARIAE CURIE-SKLODOWSKA & \\
LOL. II & SECTIO M & 2017 \\
\hline
\end{tabular}

Monika Kowalska

Uniwersytet Marii Curie-Skłodowskiej

\title{
Kolegialność działań Rady Ministrów a odpowiedzialność konstytucyjna jej członków w ocenie polskiej doktryny
}

\section{Uwagi wstępne}

Odpowiedzialność konstytucyjna, szczególnie członów egzekutywy, należy do kanonów rozwiązań konstytucyjnych współczesnych państw demokratycznych i to bez względu na przyjęte przez ustrojodawcę szczegółowe rozwiązanie systemowe. Jedną z cech charakterystycznych odpowiedzialności konstytucyjnej pozostaje jej zindywidualizowany ${ }^{1} \mathrm{i}$ ograniczony podmiotowo charakter. Dotyczy ona bowiem wyliczonej w przepisach konstytucyjnych grupy osób zajmujących najwyższe stanowiska w państwie². Stąd według art. 198 polskiej ustawy zasadniczej w Rzeczypospolitej w obecnym stanie prawnym jurysdykcji Trybunału Stanu podlegają: prezydent; członkowie Rady Ministrów; osoby, którym Prezes Rady Ministrów powierzył kierowanie ministerstwem; Prezes Narodowego Banku Polskiego; Prezes Najwyższej Izby Kontroli; członkowie Krajowej Rady Radiofonii i Telewizji; Naczelny Dowódca Sił Zbrojnych oraz posłowie i senatorowie. Zakres przedmiotowy odpowiedzialności konstytucyjnej owych najwyższych funkcjonariuszy państwa obejmuje zaś odpowiedzialność

1 Przyjmuje się obowiązywanie tzw. koncepcji osobistej odpowiedzialności za delikt konstytucyjny), co stanowi pewnego rodzaju konsekwencję upodobnienia jej charakteru do odpowiedzialności karnoprawnej. Za: M. Kowalska: Trybunat Stanu, [w:] Encyklopedia politologii. Instytucje i systemy polityczne, t. II, red. B. Dziemidok-Olszewska, W. Sokół, Wydawnictwo Wolters Kluwer, Warszawa 2012, s. 939-940.

2 Por. art. 198 ust. 1-2 Konstytucji RP z dnia 2 kwietnia 1997 r. (Dz. U. nr 78, poz. 483 ze zm.). 
za zawinione naruszenie Konstytucji lub ustawy, popełnione w związku z zajmowanym stanowiskiem lub w zakresie swojego urzędowania. Innymi słowy, Trybunał Stanu orzeka o odpowiedzialności konstytucyjnej osób zajmujących najwyższe stanowiska państwowe, za tzw. delikt konstytucyjny ${ }^{3}$. Czyn stanowiący przedmiot odpowiedzialności konstytucyjnej w praktyce może przy tym polegać zarówno na działaniu, jak i zaniechaniu (kiedy pomimo obowiązku prawnego podmiot nie podjął określonego działania). Przykładem działań zmierzających do wyegzekwowania odpowiedzialności konstytucyjnej uwarunkowanych przesłanką zaniechania było postawienie przed Trybunałem Stanu osób oskarżonych o spowodowanie niekontrolowanego napływu do Polski znacznych ilości alkoholu z zagranicy, poprzez niepodjęcie stosownych ministerialnych działań, które miałyby temu zapobiec ${ }^{4}$. Zaniechanie jako przesłanka umożliwiająca egzekwowanie odpowiedzialności konstytucyjnej została zresztą wyraźnie potwierdzona jednym z wyroków Sądu Najwyższego, zgodnie z którym „niewykonanie przez Radę Ministrów obowiązku wynikającego z kompetencji do wydania rozporządzenia zapewniającego prawidłowe wykonanie ustawy (art. 146 ust. 4 pkt 1 i 2 w związku z art. 93 Konstytucji RP) narusza konstytucyjne zasady funkcjonowania demokratycznego państwa prawnego (art. 2 i 7 Konstytucji RP), a tym samym może stanowić delikt konstytucyjny"5. Ów czyn skutkujący naruszeniem prawa może mieć przy tym różny charakter. Może to być zachowanie prawotwórcze polegające przykładowo na wydawaniu aktów normatywnych niezgodnych z posiadanymi kompetencjami, czy też stojących w sprzeczności z konstytucją lub ustawą. Może również przybrać postać zachowania decyzyjnego - polegającego na niewłaściwym stosowaniu prawa.

3 Art. 3 ustawy O Trybunale Stanu w dopełnieniu art. 198 Konstytucji RP przesądza, iż łącznie i bezwzględnie występującymi elementami definicyjnymi tego terminu są następujące jego znamiona: 1 - czyn dokonany przez konkretną osobę urzędową; 2 - niebędący przestępstwem; 3 - o charakterze zawinionym (zarówno z winy umyślnej, jak i nieumyślnej); 4 - polegający na naruszeniu Konstytucji lub ustawy (niekarnej); 5 - dokonany w związku z zajmowanym stanowiskiem lub w zakresie swego urzędowania. Za: M. Kowalska, Trybunat Stanu, [w:] Ustrój organów ochrony prawnej, red. B. Szmulik, M. Żmigrodzki, Wydawnictwo UMCS, Lublin 2005, s. 77.

4 Oskarżeni w tzw. „aferze alkoholowej” zostali: minister współpracy gospodarczej z zagranicą Dominik Jastrzębski i minister finansów Andrzej Wróblewski z rządu premiera Mieczysława Rakowskiego, minister spraw wewnętrznych Czesław Kiszczak (pełniący tę funkcję zarówno w rządzie premiera M. Rakowskiego, jak i Tadeusza Mazowieckiego) oraz minister rynku wewnętrznego w rządzie Tadeusza Mazowieckiego Aleksander Mackiewicz, a także Jerzy Ćwiek szef Głównego Urzędu Ceł. Zob. szerz.: J. Zaleśny, Odpowiedzialność konstytucyjna, Praktyka III $R P$, Oficyna Wydawnicza ASPRA-JR, Warszawa 2004, s. 59 i nast.

5 Wyrok Sądu Najwyższego z dnia 6 stycznia 1999 r. - Sygn. akt III RN 108/98, OSNIAPiUS 1999, nr 20, poz. 639. 
Jak jednak zapatrywać się na możliwe w praktyce postępowanie osób podlegających jurysdykcji Trybunału Stanu, polegające na naruszeniu porządku konstytucyjnego, ale będące efektem działań bądź zaniechań gremium, którego pozostają integralną częścią składową? Z taką możliwością, w nawiązaniu do konstytucyjnego wyliczenia w art. 198 zakresu podmiotowego odpowiedzialności konstytucyjnej, możemy mieć do czynienia w przypadku zarówno członków Rady Ministrów, jak i Krajowej Rady Radiofonii i Telewizji. Jednakowoż skoro odpowiedzialność konstytucyjna była traktowana od jej zarania przede wszystkim jako swoisty „oręż” parlamentu, pożytkowany przede wszystkim w stosunku do funkcjonariuszy władzy wykonawczej ${ }^{6}$, stąd podmiotem niniejszego artykułu uczyniono kolektyw rządowy.

Rada Ministrów pozostaje bezsprzecznie organem kolegialnym, skoro zgodnie z definicją: „kolegialność polega na zastrzeżeniu realizacji wszystkich kompetencji danego organu wieloosobowego całemu gremium, z wykluczeniem możliwości działania za kolegium któregokolwiek z jego członków [...], polega na zagwarantowaniu każdemu z członków danego wieloosobowego gremium, tworzącego dany organ, współudziału w podejmowaniu rozstrzygnięć, stanowiących realizację wszystkich kompetencji konstytucyjnych (bądź ustawowych) tego organu. W podejmowaniu tych rozstrzygnięć wszyscy członkowie mają równe prawa $[\ldots]$ ". 7 . Ten sposób działania polskiego gabinetu gwarantowany jest przede wszystkim przepisami ustawowymi, których uszczegółowienie następuje w drodze uchwały Regulamin pracy Rady Ministrów ${ }^{8}$. Do 1997 roku zasada kolegialności pozostawała zasadą konstytucyjną (por. art. 53 ust. 3 Ustawy konstytucyjnej z dnia 17 października 1992 r. O wzajemnych stosunkach między

${ }^{6}$ Por.: W. Skrzydło, Ustrój polityczny RP w świetle Konstytucji z 1997 r., Zakamycze 1998, s. 234; idem, Konstytucja Rzeczypospolitej Polskiej. Komentarz, Warszawa 2009, s. 249; M. Granat, Normatywny model odpowiedzialności konstytucyjnej w praktyce, [w:] Sady i trybunaty w konstytucji i praktyce, red. W. Skrzydło, Warszawa 2005, s. 137; J. Sobczak, Sady i trybunały, [w:] Polskie prawo konstytucyjne, red. W. Skrzydło, Wydawnictwo Verba, Lublin 2003, s. 409.

7 Za: P. Sarnecki, Nota do art. 53, [w:] Komentarz do Konstytucji Rzeczypospolitej Polskiej, t. I, red. l. Garlicki, Wydawnictwo Sejmowe, Warszawa 1995, s. 6.

8 Uchwała nr 190 Rady Ministrów z dnia 29 października 2013 roku: Regulamin pracy Rady Ministrów (M.P. 2013, poz. 979). Do 31 grudnia 2013 roku obowiązywała Uchwała nr 49 Rady Ministrów z dnia 19 marca 2002 roku: Regulamin pracy Rady Ministrów (M.P. 2002, nr 13, poz. 221 ze zm.). Dokument przyjęty w 2013 roku normuje między innymi zasady działania Rady Ministrów oraz obowiązki jej członków, a ponadto zagadnienia związane z opracowywaniem, uzgadnianiem i postępowaniem $\mathrm{z}$ wniesionymi projektami dokumentów rządowych, a także realizacją obowiązków rządu wobec Sejmu i Senatu, w tym problematykę udziału przedstawicieli Rady Ministrów w pracach parlamentarnych. Odnoście do treści regulacji regulaminu rządowego z 2002 roku zob. w: J. Hauser, Administracja publiczna, Wydawnictwo Naukowe PWN, Warszawa 2009, s. 174. 
władzą ustawodawczą i wykonawczą Rzeczypospolitej Polskiej oraz o samorządzie terytorialnym ${ }^{9}$ ). Jednak $w$ trakcie prac konstytucyjnych przeważył pogląd, iż tego rodzaju uregulowanie nie jest konieczne, działanie Rady Ministrów w procesie podejmowania decyzji w zgodzie $\mathrm{z}$ tą zasadą organizacyjną jest bowiem zrozumiałe samo przez się ${ }^{10}$.

Zasadniczą formą działania Rady Ministrów pozostają zwoływane przez premiera posiedzenia plenarne, z możliwością jednak podejmowania przez rząd decyzji również w tzw. trybie obiegowym (por. $\mathbb{2}$ pkt 2 oraz $\mathbb{\$} 92$ reg. $\mathrm{RM})^{11}$. W posiedzeniach Rady Ministrów winni uczestniczyć z prawem głosu i na równych prawach wszyscy członkowie gabinetu, realizując obowiązek aktywnego uczestnictwa w rozpatrywaniu spraw i podejmowaniu rozstrzygnięć na posiedzeniach rządu. Każdy z członków gabinetu w zakresie swego działania jest zobowiązany ponadto literą prawa do inicjowania i opracowywania polityki rządu poprzez przedkładanie inicjatyw, projektów założeń projektów ustaw i samych projektów aktów normatywnych na posiedzeniach Rady Ministrów (por. art. 7 ust. 2 uRM) ${ }^{12}$. Same rozstrzygnięcia Rady Ministrów co do zasady podejmowane są w drodze uzgodnienia, zgodnie z zasadą konsensusu. Natomiast, gdy okazałoby się to niemożliwe do osiągnięcia, premier (vel przewodniczący posiedzenia) omawiane zagadnienie może poddać pod głosowanie, w którym rozstrzygnięcie zapada większością głosów obecnych na posiedzeniu członków Rady Ministrów (z przypisaniem przewodniczącemu rozstrzygającego głosu w przypadku równego ich rozłożenia). Przy czym istotna, w kontekście chociażby ich późniejszej odpowiedzialności konstytucyjnej, pozostaje możliwość zgłoszenia do protokołu odrębnego stanowiska w stosunku do rozstrzygnięć podejmowanych na posiedzeniach Rady Ministrów.

\footnotetext{
${ }^{9}$ Dz. U. 1992, nr 84, poz. 426 ze zm.

${ }^{10}$ Por. Biuletyn Komisji Konstytucyjnej Zgromadzenia Narodowego, Warszawa 1996, nr XXXVIII, s. 89.

${ }^{11}$ Rada Ministrów może tym samym rozstrzygać sprawy na drodze korespondencyjnego uzgodnienia stanowisk. W praktyce tryb obiegowy jest jednak rzadko wykorzystywany, o czym postanawia Prezes Rady Ministrów lub działający z jego upoważnienia sekretarz Rady Ministrów. Decydując się na jego zastosowanie, wyznaczony zostaje termin na zajęcie stanowiska przez członków rządu w stosunku do przedłożonego projektu dokumentu. Projekt dokumentu rządowego skierowany do rozpatrzenia w trybie obiegowym uważa się za przyjęty, jeżeli w wyznaczonym terminie nie zgłoszono uwag do projektu. W razie zgłoszenia uwag, które nie zostaną uwzględnione lub wyjaśnione, projekt dokumentu wymaga rozpatrzenia przez Radę Ministrów na posiedzeniu.

12 Za: Ustawa z dnia 8 sierpnia 1997 r. o Radzie Ministrów (tekst jedn. Dz. U. 2012, poz. 392 ze zm.).
} 


\section{Podwójny status prawny członka Rady Ministrów}

Działania Rady Ministrów jako organu gremialnego nie podlegają co do zasady odpowiedzialności przed Trybunałem Stanu. Wykluczenie solidarnej odpowiedzialności konstytucyjnej stanowi w pewnym sensie konsekwencję upodobnienia jej charakteru do odpowiedzialności karnoprawnej i, co za tym idzie, konieczności wypełniania przez nią między innymi przesłanki zawinienia. Elementu, który z natury rzeczy ma charakter ściśle osobowy. Poza tym art. 156 Konstytucji RP o treści: „1. Członkowie Rady Ministrów ponoszą odpowiedzialność przed Trybunałem Stanu za naruszenie konstytucji lub ustaw, a także za przestępstwa popełnione w związku z zajmowanym stanowiskiem. 2. Uchwałę o pociągnięciu członka Rady Ministrów do odpowiedzialności przed Trybunałem Stanu Sejm podejmuje na wniosek Prezydenta Rzeczypospolitej lub co najmniej 115 posłów, większością 3/5 ustawowej liczby posłów", wyraźnie stanowi o podległości jurysdykcyjnej Trybunałowi Stanu „członków” Rady Ministrów, a nie samego organu państwa. W ślad niniejszego uregulowania podąża również art. 1 oraz art. 2 ust. 4 ustawy o Trybunale Stanu ${ }^{13}$. Z tej też przyczyny w powszechnej ocenie przedstawicieli doktryny prawa konstytucyjnego przyjmuje się, iż polski prawodawca ostatecznie przesądził o zindywidualizowanym charakterze odpowiedzialności przed Trybunałem Stanu osób wchodzących w skład organów kolegialnych, takich jak Rada Ministrów, a nie samych organów państwa i tym samych zrezygnował z ich odpowiedzialności w wymiarze solidarnym. Co do zasady zatem, każdy z członków gremium rządowego odpowiadać winien przed Trybunałem Stanu za własną działalność i jej prawne następstwa zgodnie z koncepcją ich osobistej odpowiedzialności za delikt konstytucyjny. Stąd nieodmiennie akcentowanym w literaturze pozostaje stricte osobisty charakter odpowiedzialności konstytucyjnej.

W szczególności też wykładnia językowa art. 198 ust. 1 Konstytucji RP prowadzi do interpretacji, iż odpowiedzialność konstytucyjna ponoszona jest w przypadku naruszenia konstytucji lub ustaw nie przez organy państwa, lecz wymienionych w tym uregulowaniu najwyższych dygnitarzy państwa, dopuszczających się naruszenia prawa w powiązaniu z ich zakresem urzędowania. Stąd definicyjnie za delikt konstytucyjny przyjmuje się czyn konkretnej osoby urzędowej, popełniony przez nią choćby nieumyślnie w związku z zajmowanym stanowiskiem lub w zakresie jej urzędowania, polegający na naruszeniu najwyższych norm prawnych w państwie. A w końcu zakresy kompetencyjne uprawniające do działania tak Radę Ministrów, jak i jej poszczególnych człon-

\footnotetext{
${ }^{13}$ Ustawa z dnia 26 marca 1982 r. o Trybunale Stanu (tj. Dz. U. 2002, nr 101, poz. 925 ze zm.).
} 
ków, działających jako jednoosobowe organy administracji rządowej, różnią się od siebie zasadniczo. Stąd każdy z członków Rady Ministrów, uczestnicząc w działaniach prawotwórczych czy decyzyjnych rządu, podjętych z naruszeniem prawa, winien liczyć się z możliwością poddania jego osoby egzekucji odpowiedzialności konstytucyjnokarnej przed Trybunałem Stanu. Rada Ministrów jako organ państwa w zaistniałej sytuacji może natomiast ponieść odpowiedzialność polityczną przed Sejmem w formule konstruktywnego wotum nieufności (por. art. 158 Konstytucji RP). W literaturze też nie bez przyczyny podkreśla się podwójny status prawny członków gabinetu ${ }^{14}$. Z jednej strony są oni oczywiście ogniwami organu kolegialnego kolektywnie uczestniczącymi w realizacji zadań Rady Ministrów, ale też z drugiej strony mają status odrębnych i samodzielnych jednoosobowych organów państwa o własnym konstytucyjnie lub ustawowo określonym zakresie kompetencyjnym.

3. Nielegalność działań Rady Ministrów a zasada indywidualizacji winy w zakresie odpowiedzialności konstytucyjnej

Takie podejście z całą pewnością stanowi utrudnienie efektywnego dochodzenia odpowiedzialności przed Trybunałem Stanu za naruszenia konstytucji lub ustaw, będących efektem podjęcia aktów prawnych, działań decyzyjnych czy zaniechań w tym zakresie przez Radę Ministrów jako organ kolegialny, w których to czynnościach z natury rzeczy partycypować co do zasady winni wszyscy członkowie gabinetu. Pamiętajmy, że prawny charakter, na dodatek zindywidualizowanej postaci odpowiedzialności konstytucyjnej, pociąga za sobą również konieczność określenia zawinienia i jego charakteru w działaniach każdego „podsądnego" ${ }^{15}$. To, przy próbie udowodnienia nielegalności działania każdego z członków wieloosobowowej Rady Ministrów, uczestniczących w działaniach czy zaniechaniach rządowych, przysporzyć musiałoby nie lada problemów. Jeżeli doszłoby bowiem do zbiegu odpowiedzialności Rady Ministrów z odpowiedzial-

${ }^{14}$ W. Skrzydło, Rada Ministrów i administracja rządowa, [w:] Polskie prawo konstytucyjne, Lublin 1998, s. 358-359

${ }^{15}$ Zasada indywidualizacji winy - przyjęta art. 21 ustawy z dnia 6 czerwca 1997 r. Kodeks karny (Dz. U. 1997, nr 88, poz. 553 ze zm.), zgodnie z którym „okoliczności osobiste, wytaczajace lub tagodzace albo zaostrzajace odpowiedzialność karna, uwzględnia się tylko co do osoby, której dotycza" - oznacza, że odpowiedzialność za czyn zabroniony ponosi jedynie sam sprawca, a wszelkie okoliczności wpływające na odpowiedzialność odnoszą się jedynie do osoby, której dotyczą. Pojęcie indywidualizacji odpowiedzialności oznacza tym samym wymóg ponoszenia skutków przez sprawcę naruszenia prawa w granicach swojej umyślności i nieumyślności, przy czym dopuszczalne jest uwzględnienie okoliczności osobistych, które mogą wpływać na łagodniejszą lub surowszą odpowiedzialność w stosunku do sprawcy, którego ona dotyczy. 
nością jej integralnych członków, współuczestniczących przy podejmowaniu decyzji lub aktu prawnego (bądź partycypujących przy zaniechaniu jego podjęcia w przypadku występowania obligatoryjnego upoważnienia ustawowego do jego wydania), co każe zakwalifikować ów czyn (polegający czy to na działaniu, czy też zaniechaniu) jako popełnienie deliktu konstytucyjnego, mogą pojawić się wątpliwości. A mianowicie, czy każdego z osobna członka organu kolegialnego należy postawić przed oblicze Trybunału Stanu, starając się sumiennie wykazywać współsprawstwo w popełnionym delikcie konstytucyjnym? A może bardziej zasadne w tej sytuacji byłoby obarczenie winą i wnioskowanie o pociągnięcie do odpowiedzialności konstytucyjnej tylko Prezesa Rady Ministrów? W końcu jego uprawnienia jako szefa rządu nie ograniczają się od roku 1997 jedynie do organizatorskich funkcji, ale pozwalają mu również merytorycznie kierować działalnością rządu. Probierzem tego pozostaje w obowiązujących przepisach konstytucyjnych choćby jego odpowiedzialność polityczna jedynie $\mathrm{w}$ formule konstruktywnego wotum nieufności ${ }^{16}$. Premier obecnie traktowany jest jako kierujący Radą Ministrów ${ }^{17}$, merytoryczne zaś, a nie jedynie organizacyjne, kierowanie Radą Ministrów przejawia się przede wszystkim w jego pozycji w stosunku do pozostałych członków rządu (funkcja koordynacyjno-kontrolna) oraz nałożeniu nań konstytucyjnego obowiązku w zakresie zapewnienia wykonania polityki Rady Ministrów oraz określania sposobów jej wykonywania (art. 148 pkt 4 i 5 Konstytucji RP). Nadzorowanym przez siebie centralnym organom administracyjnym może więc wydawać wiążące wytyczne i polecenia. Ryszard Mojak ukuł nawet tezę, iż w kontekście szerokiego zakresu uprawnień, w których zawiera się jego realna władza polityczna w stosunku do całej Rady Ministrów, jak i poszczególnych jej członków, obecna konstytucja kreuje niejako Prezesa Rady Ministrów jako czwarty podmiot ustrojowy w systemie sprawowania władzy państwowej ${ }^{18}$. Jak się wydaje zatem, wraz ze wzmocnieniem pozycji szefa

${ }^{16}$ E. Gdulewicz, R. Mojak, Rola ustrojowa i struktura organizacyjna Rady Ministrów, [w:] Ustrój i struktura aparatu państwowego i samorzadu terytorialnego, red. W. Skrzydło, Wydawnictwo Sejmowe, Warszawa 1997, s. 140.

${ }^{17}$ Zdaniem P. Winczorka premier jest rzeczywistym kierownikiem Rady Ministrów. Por: idem, Komentarz do Konstytucji Rzeczypospolitej Polskiej, z dnia 2 kwietnia 1997 r., Wydawnictwo Liber, Warszawa 2000, s. 195. Podobnie sądzą: S. Patyra, Prawnoustrojowy status Prezesa Rady Ministrów w świetle Konstytucji z 2 kwietnia 1997 r., Wydawnictwo Sejmowe, Warszawa 2002, s. 87; B. Banaszak, Prawo konstytucyjne, Warszawa 2001, s. 595; J. Jagielski, Administracja centralna, [w:] Prawo administracyjne, red. M. Wierzbowski, Wydawnictwo LexisNexis, Warszawa 2002, s. 168.

${ }^{18}$ Por. R. Mojak, Status ustrojowy Rady Ministrów w nowej Konstytucji Rzeczypospolitej Polskiej (zagadnienia wybrane), [w:] Ustrój polityczny Rzeczypospolitej Polskiej w nowej Konstytucji z 2 kwietnia 1997 roku. XL Ogólnopolska Konferencja Katedr Prawa Konstytucyjnego 4-6 czerwca 1998, Kazimierz Dolny nad Wista, red. W. Skrzydło, R. Mojak, Wydawnictwo UMCS, Lublin 1998, s. 75. Do stanowiska tego przychylił się również P. Sarnecki, wyliczając, iż kompetencje 
polskiego rządu w stosunku do pozostałych członków jego gabinetu, powinno następować rozszerzenie zakresu jego odpowiedzialności. Oczywiście jednak tylko w zakresie wyznaczonym mu przez przepisy ustawy zasadniczej. Stąd, pozostając $\mathrm{w}$ zgodzie $\mathrm{z}$ zasadą indywidualizacji winy, $\mathrm{w}$ tym przypadku premier mógłby jedynie odpowiadać w kontekście uregulowań art. 148 pkt 2 i 5 Konstytucji RP, które przypisują mu kierowniczą rolę w pracach Rady Ministrów i zobowiązują do koordynowania i kontroli prac członków rządu. Szczególnie, że nastąpiło porzucenie formuły primus inter pares na rzecz koncepcji primatum tenens. W tym wypadku podstawę wniosku mogłoby stanowić niedopełnienie konstytucyjnych obowiązków przez Prezesa Rady Ministrów w kontekście działania kolegium, do przewodzenia któremu został powołany, i tym samym uniknęlibyśmy sytuacji, w której Prezes Rady Ministrów odpowiadałby przed organem władzy sądowniczej także za cudze działania. Jest to o tyle warte rozważenia, iż w przypadku udowodnienia przed Trybunałem Stanu w tej sytuacji naruszenia ustawy zasadniczej przez Prezesa Rady Ministrów, to nawet w przypadku nieumyślności jego działań w tym zakresie każdorazowym efektem byłoby pozbawienie go stanowiska, a tym samym upadek całego jego gabinetu i konieczność powołania nowej Rady Ministrów. Patrząc jednak przez pryzmat dotychczasowej praktyki, charakteryzującej się przewlekłością toczących się postępowań w przedmiocie egzekwowania odpowiedzialności konstytucyjnej, śmiem wątpić, aby którekolwiek z ewentualnych działań prawnych, skierowanych personalnie wobec Prezesa Rady Ministrów, nawet sankcjonujących pośrednio działania kolegium rządowego, działającego pod jego kierownictwem, miałoby szanse zakończyć się w perspektywie „pełnokadencyjnego” okresu funkcjonowania danego gabinetu. A zatem sankcje natury politycznej, wyrażone w formule wotum nieufności w stosunku do nielegalnych działań Rady Ministrów, zapewne okazałyby się o wiele bardziej efektywne w takiej sytuacji.

Pewnego rodzaju konsternację i kontrowersje w zakresie możliwości egzekwowania odpowiedzialności konstytucyjnej w wymiarze solidarnym wzbudziło jedno z orzeczeń Sądu Najwyższego ${ }^{19}$, który stwierdził w uzasadnieniu, iż „bezczynność Rady Ministrów w zakresie realizacji kompetencji do wydania rozporządzenia niezbędnego w celu zapewnienia wykonania ustawy stanowi (art. 146 ust. 4 pkt 1 i 2 w związku z art. 92 Konstytucji RP) delikt konstytucyjny

osobiste premiera na polu administracji publicznej należą do najrozleglejszych, stąd zastanawiał się nad tym, czy nie zasadnym byłoby wpisanie Prezesa Rady Ministrów do art. 10 ust. 2 konstytucji. Por. idem, Kierownicze kompetencje Prezesa Rady Ministrów w strukturze administracji rzadowej, „Przegląd Sejmowy”, 2011, nr 3 (104), s. 71.

${ }^{19}$ Wyrok Sądu Najwyższego z dnia 6 stycznia 1999 r. - Sygn. akt III RN 108/98, OSNIAPiUS 1999, nr 20, poz. 639. 
i objęty jest odpowiedzialnością konstytucyjną przed Trybunałem Stanu (art. 198 ust. 1 Konstytucji RP)", stanowiąc przy tym „naruszenie praw uprawnionych podmiotów, a tym samym konstytucyjnych zasad funkcjonowania demokratycznego państwa prawnego (art. 2 i 7 Konstytucji RP z dnia 2 kwietnia 1997)"20. Tym samym Sąd Najwyższy jako delikt konstytucyjny potraktował bezczynność (zaniechanie) Rady Ministrów (kolegialnego organu państwa), polegającą na niepodjęciu stosownych działań prawodawczych, wynikających $\mathrm{z}$ upoważnienia ustawowego zobowiązującego rząd do wydania rozporządzenia celem wykonania stosownej ustawy przedmiotowej. Wydaje się zatem, iż Sąd Najwyższy swoim orzeczeniem wyraził pogląd, iż zakres przedmiotowy odpowiedzialności konstytucyjnej może obejmować nie tylko zaniechanie skutkujące naruszeniem konstytucyjnych czy ustawowych obowiązków przez organ o charakterze monokratycznym, ale również i działającego in gremio organu państwa, którego członkowie podlegają jurysdykcji Trybunału Stanu. Tym samym uznanie bezczynności Rady Ministrów za delikt konstytucyjny, zdaniem sądu, winno stanowić niejako podstawę do wszczęcia procedury egzekwowania solidarnej odpowiedzialności konstytucyjnej wobec jej członków, partycypujących ex lege w tym zaniechaniu, skutkującym niewywiązaniem się z nałożonego nań obowiązku konstytucyjnoustawowego.

Stojąc jednak w opozycji do stanowiska zaprezentowanego przez Sąd Najwyższy, większość konstytucjonalistów stwierdziła, że kwalifikacja przedmiotowa odpowiedzialności konstytucyjnej nie przesądza jeszcze automatycznie o łącznej odpowiedzialności Rady Ministrów ${ }^{21}$. W ocenie doktryny, co zostało wcześniej wielokrotnie podkreślone, odpowiedzialność konstytucyjna miała bowiem zawsze charakter zindywidualizowany ${ }^{22}$. Wynikać to miałoby chociażby z samej jej proweniencji, jak również, w przypadku członków egzekutywy,

${ }^{20}$ Zob.: Uzasadnienie do wyroku Sądu Najwyższego z dnia 6 stycznia 1999 r., [w:] Informacje - Orzecznictwo innych sadów, „Przegląd Sejmowy”, 1999, nr 4 (33), s. 225.

${ }^{21}$ Zob. W. Kręcisz, Glosa glosy do wyroku Sadu Najwyższego z 6 stycznia 1999 r. (sygn. akt III RN 108/98), „Przegląd Sejmowy”, 1999, nr 4 (33), s. 226-234; A. Wasilewski, List do redakcji w sprawie glosy do wyroku Sadu najwyższego z 6 stycznia 1999 r. (sygn. akt III RN 108/98 OSNIAPiUS 1999, nr 20, poz. 639) opublikowane w „Przegladzie Sejmowym” z 1999 r., nr 4, „Przegląd Sejmowy”, 2000, nr 2 (37), s. 263-265; R. Mojak, Parlament a Rzad w ustroju Trzeciej Rzeczypospolitej Polskiej, Wydawnictwo UMCS, Lublin 2007, s. 608-609.

${ }^{22}$ Nie jest to do końca prawdą w przypadku polskich uregulowań prawnych. Chociażby art. 56 Konstytucji RP z 17 marca 1921 roku przewidywał nie tylko zindywidualizowaną, ale również solidarną postać odpowiedzialności konstytucyjnej Rady Ministrów (obok odpowiedzialności parlamentarnej). Zgodnie bowiem z ówczesnymi postanowieniami konstytucyjnymi, rząd ponosić miał solidarną odpowiedzialność, tak parlamentarną, jak i konstytucyjną, za ogólny kierunek działalności Rady Ministrów. Poszczególni członkowie gabinetu mogli zaś zostać postawieni przed Trybunałem Stanu, będąc winni naruszeń konstytucji lub ustaw w przyznanym im zakre- 
możliwości jej łącznego rozpatrywania z odpowiedzialnością karną, a także wreszcie „podparcia” się przez ustawodawcę w działaniach Trybunału Stanu procedurą karną. Natomiast nie ma jednolitego stanowiska, czy za działania organu kolegialnego, podejmowane z naruszeniem prawa, winni odpowiadać przed Trybunałem Stanu wszyscy jego członkowie, czy też dopuszczalne byłoby na mocy obowiązującego prawa postawienie w stan oskarżenia i osądzenie tylko jego niektórych członków?

\section{Doktrynalne ujęcie problemu odpowiedzialności konstytucyjnej za działania kolektywu rządowego}

Już z chwilą wejścia w życie w pierwotnej wersji ustawy o Trybunale Stanu, poddającej jurysdykcji tegoż organu naruszających prawo członków, również wieloosobowych gremiów, takich jak Rada Ministrów oraz Rada Państwa, Zofia Świda-Łagiewska ${ }^{23}$ stanęła na stanowisku, iż działania organu wieloosobowego nie podlegają odpowiedzialności konstytucyjnej, osoby zaś wchodzące w skład owych gremiów ponoszą odpowiedzialność jedynie za czyny, których dopuściłyby się w wyznaczonym indywidualnie zakresie ich urzędowania, nie mogąc tym samym ponosić odpowiedzialności przed Trybunałem Stanu za działania podjęte kolegialnie jako Rada Ministrów (analogicznie również do przypadku ówcześnie działającej Rady Państwa). Podobnie Michał Pietrzak ${ }^{24}$, powołując się na ówczesne brzmienie ustawy przedmiotowej, zgodnie z którą odpowiedzialności konstytucyjnej miały podlegać „osoby zajmujące najwyższe stanowiska państwowe”, a tym samym domniemając jedynie zindywidualizowany jej charakter, odżegnywał się od możliwości solidarnej odpowiedzialności przed Trybunałem Stanu za działania lub zaniechania Rady Ministrów, funkcjonującej w formule organu kolegialnego. Jednocześnie zastrzegał, iż jego zdaniem ciężarem odpowiedzialności za działania i decyzje rządu nie powinno się obciążać również jedynie Prezesa Rady Ministrów, z jednoczesnym wyłączeniem możliwości partycypacji w odpowiedzialności pozostałych członków gabinetu za działania owego gremium. Wręcz przeciwnie, jego zdaniem, winni oni na równi odpowiadać za sprzeczne z prawem działania Rady Ministrów lub jej zaniechania, jeżeli owych działań lub zaniechań byliby bezpośrednimi sprawcami. A to należało tłumaczyć w kontekście ich aktywnego uczestnictwa w obradach rządu. Stąd, poza zakresem takowej odpowiedzialności,

sie działania bądź też za sprzeczne z najwyższym prawem działania podległych im organów oraz kontrasygnowane przezeń akty urzędowe głowy państwa.

${ }^{23}$ Por. Z. Świda-Łagiewska, Zasady odpowiedzialności konstytucyjnej i system kar, [w:] Trybunat Stanu w PRL, Warszawa 1983, s. 131 oraz 133-134.

${ }^{24}$ M. Pietrzak, Odpowiedzialność konstytucyjna w Polsce, Warszawa 1992, s. 102-103. 
mogliby pozostać jedynie ministrowie nieuczestniczący w podejmowaniu niekonstytucyjnej decyzji bądź ci, którzy w trakcie głosowania negowali jej podjęcie.

Z kolei Jerzy Wróblewskii ${ }^{25}$ zgłębiając tematykę odpowiedzialności konstytucyjnej, zauważył, iż w sytuacji podjęcia z naruszeniem najwyższego prawa decyzji przez kolegialny organ państwa, w praktyce zastosowanie mogłyby znaleźć następujące możliwości: 1) odpowiedzialności winni podlegać wszyscy członkowie kolegium, uczestniczący w obradach, podczas których zapadła owa decyzja - niezależnie od ich stanowiska w sprawie; 2 ) odpowiadać powinni jedynie ci członkowie organu kolegialnego, którzy głosowali za podjęciem rozstrzygnięcia; 3) odpowiadać powinni wszyscy uczestnicy posiedzenia, z wyjątkiem osób głosujących przeciw podjęciu decyzji; 4) odpowiedzialność ponosi kierujący pracami organu kolegialnego - ale to rozwiązanie byłoby, jego zdaniem, błędne w sytuacji braku prawnych podstaw uzasadniających szczególną kierowniczą rolę przewodniczącego organu kolegialnego; 5) nikt w tej sytuacji nie powinien, spośród członków kolegialnego organu, ponieść odpowiedzialności konstytucyjnej. Stanął na stanowisku, iż najbardziej uzasadniony byłby wybór między wariantem drugim i trzecim. Sam wybór winien być podyktowany przede wszystkim skutkiem, jaki miałyby wywierać „głosy wstrzymujące się". W przypadku głosowań opartych na regule większości bezwzględnej czy kwalifikowanej, "głosy wstrzymujące się" utrudniają podjęcie ostatecznego rozstrzygnięcia przez gremium głosujących, a zatem w zasadzie można je zaliczyć do grupy głosów przeciwnych podjęciu danej decyzji. Stąd, przy obowiązywaniu takiej formuły głosowania, należałoby oczekiwać egzekwowania odpowiedzialności konstytucyjnej jedynie od tych członków organu wieloosobowego, którzy w wyraźny sposób głosując na „tak”, opowiedzieli się za naruszającym prawo rozstrzygnięciem. Natomiast przy stosowaniu podczas głosowań reguły większości względnej - gdzie dla podjęcia wiążącej decyzji potrzeba więcej głosów „za” niż „przeciw”, a głosy „wstrzymujących się” nie są brane pod uwagę - oznaczać by to musiało przyjęcie wariantu trzeciego, pozwalającego na egzekwowanie odpowiedzialności konstytucyjnej wszystkich członków gremium, partycypujących w podjęciu ostatecznego rozstrzygnięcia, z wyjątkiem osób wyraźnie się temu sprzeciwiających.

Również w późniejszych rozważaniach doktrynalnych trudno o jednolitość stanowiska. Podobne do zaprezentowanego przez Michała Pietrzaka zajął chociażby Romuald Kmiecik ${ }^{26}$, którego zdaniem za działania Rady Ministrów, pod-

${ }^{25}$ J. Wróblewski, Delikt konstytucyjny, Warszawa 1985, s. 17-18.

${ }^{26}$ R. Kmiecik, Opinia prawna o możliwości wszczęcia postępowania w zakresie odpowiedzialności konstytucyjnej wobec członka organu kolegialnego (na przyktadzie KRRiT), [w:] Postępowanie przed Komisją Odpowiedzialności Konstytucyjnej. Zagadnienia modelowe, Biuro Analiz Sejmowych Kancelarii Sejmu, Warszawa 2007, s. 96-97; R. Kmiecik, W sprawie możliwości 
jęte z naruszeniem ustawy zasadniczej lub innych ustaw, nie może odpowiadać członek gabinetu, który nie uczestniczył w głosowaniu nad ich podjęciem albo gdy sprzeciwiał się w sposób wyraźny jego podjęciu. Postulował przy tym, aby charakter nagannego zachowania członka organu kolegialnego, dopuszczającego się „w związku z zajmowanym stanowiskiem lub w zakresie swego urzędowania” deliktu konstytucyjnego, został wyraźnie dookreślony. Niezawinione bowiem działanie członka kolegium, choćby czynności podjęte przez Radę Ministrów naruszały konstytucję lub ustawy, jego zdaniem nie są wystarczającym uzasadnieniem do wszczęcia przez organy sejmowe procedury w przedmiocie odpowiedzialności konstytucyjnej. Zwracał przy tym uwagę, że jeżeli członek rządu dopuściłby się w związku z zajmowanym stanowiskiem lub w zakresie swego urzędowania naruszenia konstytucji lub ustaw w wyniku przestępstwa, to niepociągnięcie członka Rady Ministrów za ów czyn do odpowiedzialności przed Trybunałem Stanu otwiera drogę do jego sankcjonowania przez powszechny sąd karny. Porównywalnie Wojciech Odrowąż-Sypniewski ${ }^{27}$, przyjmując za regulaminem pracy Rady Ministrów tryb uzgodnieniowy jako zasadniczą formułę podejmowania rozstrzygnięć na forum rządowym, stanął na stanowisku, iż odpowiedzialności konstytucyjnej w tej sytuacji za działania podjęte z naruszeniem prawa winni podlegać wszyscy członkowie Rady Ministrów, uczestniczący w posiedzeniu gabinetu, na którym owa decyzja zapadła. W przypadku zaś przeprowadzenia głosowania w sprawie z odpowiedzialności winni zostać zwolnieni jedynie ci członkowie gabinetu, którzy wyrazili wyraźny sprzeciw wobec decyzji kolegium.

Paweł Sarnecki ${ }^{28} \mathrm{z}$ kolei, powołując się przede wszystkim na brzmienie art. 3 uTS, stanowiącego, iż odpowiedzialność konstytucyjna obejmuje czyny, którymi "osoby" wymienione w ustawie, w związku z zajmowanym stanowiskiem lub w zakresie swojego urzędowania, chociażby nieumyślnie naruszyły konstytucję lub ustawę, odrzucił oczywiście możliwość solidarnej odpowiedzialności członków gremium rządowego za popełnienie deliktu konstytucyjnego, jako że

wszczęcia postępowania w przedmiocie odpowiedzialności konstytucyjnej członka organu kolegialnego (na przykładzie KRRiT), „Przegląd Sejmowy”, 2008, nr 2, s. 160-161.

${ }^{27}$ W. Odrowąż-Sypniewski, Odpowiedzialność konstytucyjna członków organów kolegialnych, „Przegląd Sejmowy”, 2006, nr 6, s. 111-112; W. Odrowąż-Sypniewski, Odpowiedzialność konstytucyjna członków organów kolegialnych, [w:] Postępowanie przed Komisją Odpowiedzialności Konstytucyjnej. Zagadnienia modelowe, Biuro Analiz Sejmowych Kancelarii Sejmu, Warszawa 2007, s. 68.

${ }^{28}$ P. Sarnecki, Opinia o możliwości wszczęcia postępowania w zakresie odpowiedzialności konstytucyjnej wobec członka organu kolegialnego, [w:] Postępowanie przed Komisja Odpowiedzialności Konstytucyjnej. Zagadnienia modelowe, Biuro Analiz Sejmowych Kancelarii Sejmu, Warszawa 2007, s. 100-102; P. Sarnecki, W sprawie możliwości wszczęcia postępowania w przedmiocie odpowiedzialności konstytucyjnej członka organu kolegialnego (na przykładzie KRRiT), „Przegląd Sejmowy”, 2008, nr 2, s. 162-164. 
brzmienie wzmiankowanego przepisu, jego zdaniem, daje wyraźną podstawę egzekucji odpowiedzialności konstytucyjnej jedynie konkretnych osób, a nie organów państwa jako takich. Wskazane konstytucyjnie osoby ową odpowiedzialność przed Trybunałem Stanu, za swój wkład w podjęte z naruszeniem prawa działania, mogą ponosić nawet wówczas, gdy stanowią jedynie składową kolegialnego organu państwa. Powołując się przy tym na analogię odpowiedzialności konstytucyjnej i procedury jej egzekwowania do odpowiedzialności prawnokarnej, wskazywał, iż w końcu zgodnie z art. 20 Kodeksu karnego „każdy ze współdziałających w popełnieniu czynu zabronionego odpowiada w granicach swej umyślności lub nieumyślności niezależnie od odpowiedzialności pozostałych współdziałających" ${ }^{29}$. Rada Ministrów zaś, jego zdaniem, jako gremialny organ państwa, w zaistniałej sytuacji może jedynie ponieść odpowiedzialność polityczną przed Sejmem, gdzie podstawę wniosku o udzielenie gabinetowi wotum nieufności może stanowić twierdzenie, iż rząd dopuścił się złamania najwyższego prawa przy podejmowaniu decyzji czy działań prawotwórczych mu przypisanych lub w związku z ich zaniechaniem. W odpowiedzialności konstytucyjnej występuje bowiem element winy, który można przypisać wyłącznie konkretnej osobie, ale już nie organowi państwa. Stąd premier rządu i jego ministrowie, stanowiąc elementy składowe wieloosobowego organu państwa, jakim pozostaje Rada Ministrów, chociażby, jak stanowi art. 3 uTS, „nieumyślnie” przyczynili się do naruszenia konstytucji lub ustawy, mogą zostać postawieni w stan oskarżenia przed Trybunał Stanu. P. Sarnecki stanął przy tym na stanowisku, że w opisanej sytuacji należałoby wnioskować o postawienie w stan oskarżenia wszystkich członków Rady Ministrów, gdyż, co do zasady, członkowie rządowego kolegium w Polsce mają zapewniony, literą wyżej wskazanych przepisów regulaminowych, równy wpływ na zapadające $w$ nim decyzje. Zdaniem P. Sarneckiego, prawny obowiązek objęcia zakresem ewentualnego wniosku wstępnego o pociągnięcie do odpowiedzialności konstytucyjnej wszystkich członków organu kolegialnego w sytuacji, gdy gremium to podjęło rozstrzygnięcie naruszające konstytucję lub ustawę, winno dotyczyć nawet tych osób, które były nieobecne na posiedzeniu w dniu podejmowania rozstrzygnięcia rządowego. Takie podejście wynika z tego, iż trudno jest, jego zdaniem, z góry założyć, że nie mogły mieć one wpływu na treść ustanowionego prawa czy podjętej decyzji przez Radę Ministrów.

Również Dariusz Zrębiec ${ }^{30}$ zwracał uwagę na możliwość zagospodarowania konstrukcji wypracowanych w prawie karnym - takich jak współsprawstwo czy

${ }^{29}$ Ustawa z dnia 6 czerwca 1997 r. Kodeks karny, (Dz. U. 1997, nr 88, poz. 553 ze zm.).

${ }^{30}$ D. Zrębiec, Zakres podmiotowy i przedmiotowy odpowiedzialności konstytucyjnej w nowej Konstytucji RP (wybrane zagadnienia), „Annales Universitatis Mariae Curie-Sklodowska”, 1999, sectio G, vol. XLVI, s. 223. 
pomocnictwo - dla prawidłowego zakwalifikowania zachowania się podmiotu (również będącego uczestnikiem nielegalnych działań kolegialnego organu państwa), dopuszczającego się deliktu konstytucyjnego. W jego opinii jednak - z racji braku występowania w ustawie o Trybunale Stanu przepisu wprost odsyłającego do odpowiednich uregulowań Kodeksu karnego - takie bezpośrednie przenoszenie i stosowanie rozwiązań prawa karnego na gruncie prawa konstytucyjnego nie jest uzasadnione i nie może być akceptowane w szerokim kontekście, ze względu na specyficzny charakter chociażby samego deliktu konstytucyjnego. Stąd jego zdaniem nie powinno się stawiać zarzutów naruszenia konstytucji lub ustaw osobom, których zachowanie, choć wyczerpywałoby znamiona współsprawstwa, podżegania czy pomocnictwa, lecz których ustawa zasadnicza nie zdefiniowałaby jednocześnie jako podmioty ponoszące odpowiedzialność konstytucyjną. Tą drogą mogłoby bowiem dojść pośrednio do rozszerzenia kręgu osób ponoszących odpowiedzialność konstytucyjną przed Trybunałem Stanu. Jednakże, w interesującym nas zakresie - każdy z członków Rady Ministrów, uczestniczący w pracach rządu, wypełnia wskazanie podmiotowe wynikające z art. 198 Konstytucji RP, stąd ewentualne posiłkowanie się wyżej przytoczonymi instytucjami prawa karnego można potraktować jako czynnik sprawiający, że ocena zachowania podmiotu dopuszczającego się deliktu byłaby kompleksowa i obejmowałaby wszystkie elementy podlegające ujemnemu wartościowaniu.

Kazimierz Zgryzek ${ }^{31}$ na pytanie o to, czy osobie wchodzącej w skład organu podejmującego decyzje kolegialnie można postawić zarzut odpowiedzialności konstytucyjnej lub konstytucyjnokarnej w sytuacji, gdy rozstrzygnięcie podjęte zostało z naruszeniem konstytucji lub ustawy przez wieloosobowy organ, udzielił pozytywnej odpowiedzi, nie widząc przeszkód, aby u podstaw podjęcia próby wyegzekwowania odpowiedzialności przed Trybunałem Stanu leżał czyn podjęty przez zbiorowość osób. Oczywiście wina każdego z członków rządowego kolegium powinna zostać przy tym skonkretyzowana i zindywidualizowana. Przy czym również, jego zdaniem, odpowiedzialność za treść podjętego przez Radę Ministrów rozstrzygnięcia winni ponosić wszyscy jej członkowie, a nie tylko ci, którzy głosowali za jego przyjęciem. Stanowisko swoje oparł przede wszystkim na możliwości (zgodnie z art. 18 uTS) odpowiedniego stosowania przepisów procedury karnej, zgodnie z którą „sąd właściwy dla sprawców przestępstw jest

${ }^{31} \mathrm{~K}$. Zgryzek, Opinia prawna o możliwości wszczęcia postępowania w zakresie odpowiedzialności konstytucyjnej wobec członka organu kolegialnego (na przykładzie KRRiT), [w:] Postępowanie przed Komisja Odpowiedzialności Konstytucyjnej. Zagadnienia modelowe, Biuro Analiz Sejmowych Kancelarii Sejmu, Warszawa 2007, s. 92-94; K. Zgryzek, W sprawie możliwości wszczęcia postępowania w przedmiocie odpowiedzialności konstytucyjnej członka organu kolegialnego (na przyktadzie KRRiT), „Przegląd Sejmowy”, 2008, nr 2, s. 165-167. 
również właściwy dla pomocników, podżegaczy oraz innych osób, których przestępstwo pozostaje w ścisłym związku z przestępstwem sprawcy, jeżeli postępowanie przeciwko nim toczy się jednocześnie”, przesądzając także o tym, iż „sprawy tych osób powinny być połączone we wspólnym postępowaniu" ${ }^{32}$. Oznacza to, że jeżeli został popełniony czyn przez większą liczbę osób i ich działania pozostają ze sobą w ścisłym związku, to postępowanie karne powinno być prowadzone przeciwko nim łącznie, w nawiązaniu do zasady niepodzielności przedmiotu procesu. Niedopuszczalne jest bowiem, zgodnie z tą zasadą, wszczęcie postępowania przeciwko jednej osobie o czyn naruszający ustawę zasadniczą lub karną, przy jednoczesnej rezygnacji dochodzenia odpowiedzialności karnej pozostałych osób, które partycypowały, wchodząc w skład wieloosobowego organu w podjęciu przezeń decyzji naruszającej prawo. Stąd stanął na stanowisku, iż niewłaściwe byłoby podejście zezwalające na „wybiórcze” wszczynanie postępowania przed Trybunałem Stanu za naruszające konstytucję i ustawy działania Rady Ministrów wobec jedynie części osób tworzących kolegium rządowe.

Paweł Wiliński ${ }^{33}$ z kolei, wychodząc z założenia, iż kolegialność rozmywa w pewnym sensie odpowiedzialność i znacznie zmniejsza jej dolegliwość, a także nie daje możliwości polaryzowania samej odpowiedzialności poprzez uwzględnienie stopnia partycypacji członków gremialnego organu decyzyjnego oraz podkreśliwszy, iż podstawą odpowiedzialności przed Trybunałem Stanu jest udowodnienie popełnienia czynu zabronionego, choćby z winy nieumyślnej, przyjął za możliwy na gruncie obowiązujących przepisów do praktycznej realizacji wariant pozwalający na pociągnięcie do odpowiedzialności konstytucyjnej tylko niektórych członków organu kolegialnego. Bierze się to, jego zdaniem, chociażby z konieczności uwzględnienia tego, kto z wieloosobowego gremium uczestniczył w procedurze decyzyjnej i głosował „za”, a kto „przeciw” podjęciu konkretnej decyzji naruszającej najwyższe prawodawstwo. Zwracał przy tym uwagę na fakt, iż rola niektórych osób, wchodzących w skład decyzyjnego gremium, może być istotniejsza od pozostałych - na przykład inicjatorów czy projektodawców działań rządowych podjętych z naruszeniem prawa, osób aktywnie uczestniczących $\mathrm{w}$ dyskusji czy wreszcie przewodniczącego posiedzenia, prowadzącego głosowanie w określony sposób. To dawałoby jego zdaniem możliwość ograniczenia zakresu wniosku wstępnego o pociągnięcie do odpowiedzialności konstytucyjnej tylko do niektórych osób, wchodzących w skład Rady

${ }^{32}$ Por. art. 34 $₫ 1-2$ ustawy z dnia 6 czerwca 1997 r. Kodeks postępowania karnego (Dz. U. 1997, nr 89, poz. 555 ze zm.).

${ }^{33}$ P. Wiliński, Wszczęcie postępowania w przedmiocie odpowiedzialności konstytucyjnej członka organu kolegialnego, [w:] Postępowanie przed Komisją Odpowiedzialności Konstytucyjnej. Zagadnienia modelowe, Biuro Analiz Sejmowych Kancelarii Sejmu, Warszawa 2007, s. 87-88. 
Ministrów, ale oczywiście przy szczegółowym uzasadnieniu owego ograniczenia podmiotowego. Podobnego zdania jest Zbigniew Gromek $^{34}$, dla którego poczynania organu wieloosobowego również mogą stanowić podstawę egzekwowania zindywidualizowanej odpowiedzialności konstytucyjnej osób podlegających kognicji Trybunału Stanu, a uczestniczących aktywnie w działaniach podjętych z naruszeniem prawa przez dany kolektyw, którego integralną część owe podmioty stanowią. Odpowiedzialność konstytucyjną osób wymienianych przez ustawę zasadniczą, a stanowiących komponenty wieloosobowych organów państwa (tj. członkowie Rady Ministrów, członkowie Krajowej Rady Radiofonii i Telewizji), również w kontekście działania samego szerszego gremium, traktuje jako realizację ogólnej dyrektywy, wedle której maksymalnie szeroki katalog potencjalnych naruszeń prawa przez najwyższych dygnitarzy państwowych winien podlegać reżimowi odpowiedzialności konstytucyjnej, nawet jeżeli dane działanie w sensie prawnym przypisujemy organowi kolegialnemu. Podkreślił przy tym wyraźnie, iż odpowiedzialność takowa jest możliwa jednakże jedynie w sytuacji, gdy istnieje szansa przypisania winy danemu członkowi organu wieloosobowego.

Przychylając się do stanowiska, że poczynania członków Rady Ministrów, działających in gremio (tj. jako integralna część kolektywu rządowego) i partycypujących tym samym w jego ewentualnych poczynaniach decyzyjnych, podejmowanych z naruszeniem prawa, winny stanowić na równi podstawę ich odpowiedzialności prawnej przed Trybunałem Stanu co działania podejmowane $\mathrm{z}$ naruszeniem prawa, ale już w ramach im przypisanego zakresu działania jako jednoosobowych organów państwa, warto posłużyć się przykładem. I choć nie dotyczy on bezpośrednio członków Rady Ministrów, jest on wydatnie rzucającym światło na omawiane zagadnienie. Należy bowiem w tym miejscu przypomnieć, iż, zgodnie z obecnie obowiązującą ustawą zasadniczą, obok członków gremium rządowego również członkowie Krajowej Rady Radiofonii i Telewizji zostali włączeni w poczet funkcjonariuszy państwa podlegających jurysdykcji Trybunału Stanu. W tym przypadku jednak, bez żadnej wątpliwości, ich zakres kompetencyjny może realizować się wyłącznie w formule wypełniania funkcji członka tego wieloosobowego organu państwa i podejmowaniu działań w jego ramach, nie będąc jednocześnie przy tym zaopatrzonym w kompetencje własne. Członkowie Krajowej Rady Radiofonii i Telewizji nie dysponują bowiem statusem monokratycznego organu państwa. Trudny zatem do obrony byłby w tym przypadku koncept zakładający, iż ustrojodawca, choć poddawszy ich z mocy prawa kognicji Trybunału Stanu, jednocześnie zakazał poddania ich

${ }^{34}$ Z. Gromek, Odpowiedzialność konstytucyjna a kontrola sejmowa. Wybrane zagadnienia, „Przegląd Sejmowy”, 2008, nr 3, s. 68-71. 
jego osądowi w kontekście podjętych działań przez organ kolegialny, którego integralną część stanowią. Byłoby to bowiem założenie wewnętrznie sprzeczne. Zasadne, jak się wydaje, jest również przyjęcie założenia, iż odpowiedzialności konstytucyjnej za działania podjęte z naruszeniem prawa przez Radę Ministrów winni podlegać wszyscy jej członkowie uczestniczący w posiedzeniu rządu, na którym owa decyzja zapadła na zasadzie konsensusu. A gdyby niemożność jego osiągnięcia wymuszało potrzebę przeprowadzenia głosowania w sprawie, jedynie wyraźny sprzeciw wyrażony przy podejmowaniu decyzji przez członka Rady Ministrów mógłby go zwolnić z partycypowania w odpowiedzialności konstytucyjnej w tym zakresie.

\section{Bibliografia}

\section{Źródła}

- Konstytucja Rzeczypospolitej Polskiej z dnia 2 kwietnia 1997 r. (Dz. U. nr 78, poz. 483 ze zm.).

- Ustawa konstytucyjna z dnia 17 października 1992 r. o wzajemnych stosunkach między władzą ustawodawczą i wykonawczą Rzeczypospolitej Polskiej oraz o samorządzie terytorialnym (Dz. U. 1992, nr 84, poz. 426 ze zm.).

- Ustawa z dnia 26 marca 1982 r. o Trybunale Stanu (tj. Dz. U. 2002, nr 101, poz. 925 ze zm.).

- Ustawa z dnia 6 czerwca 1997 r. Kodeks karny (Dz. U. 1997, nr 88, poz. 553 ze zm.).

- Ustawa z dnia 6 czerwca 1997 r. Kodeks postępowania karnego (Dz. U. 1997, nr 89, poz. $555 \mathrm{ze}$ zm.).

- Ustawa z dnia 8 sierpnia 1997 r. o Radzie Ministrów (tekst jedn. Dz. U. 2012, poz. 392 ze zm.).

- Uchwała nr 49 Rady Ministrów z dnia 19 marca 2002 r. Regulamin prac Rady Ministrów (M.P. 2002, nr 13, poz. 221 ze zm.).

- Uchwała nr 190 Rady Ministrów z dnia 29 października 2013 r. Regulamin prac Rady Ministrów (M.P. 2013, poz. 979).

- Wyrok Sądu Najwyższego z dnia 6 stycznia 1999 r. - Sygn. akt III RN 108/98, OSNIAPiUS 1999, nr 20, poz. 639.

- Biuletyn Komisji Konstytucyjnej Zgromadzenia Narodowego, Warszawa 1996, nr XXXVIII.

\section{Piśmiennictwo naukowe}

- Banaszak B., Prawo konstytucyjne, Wydawnictwo C.H. Beck, Warszawa 2001.

- Gdulewicz E., Mojak R., Rola ustrojowa i struktura organizacyjna Rady Ministrów, [w:] Ustrój i struktura aparatu państwowego i samorzadu terytorialnego, red. W. Skrzydło, Wydawnictwo Sejmowe, Warszawa 1997.

- Granat M., Normatywny model odpowiedzialności konstytucyjnej w praktyce, [w:] Sady i trybunały w konstytucji i praktyce, red. W. Skrzydło, Wydawnictwo Sejmowe, Warszawa 2005. 
- Gromek Z., Odpowiedzialność konstytucyjna a kontrola sejmowa. Wybrane zagadnienia, „Przegląd Sejmowy”, 2008, nr 3.

- Hauser J., Administracja publiczna, Wydawnictwo Naukowe PWN, Warszawa 2009.

- Jagielski J., Administracja centralna, [w:] Prawo administracyjne, red. M. Wierzbowski, Wydawnictwo LewisNexis, Warszawa 2002.

- Kmiecik R., Opinia prawna o możliwości wszczęcia postępowania w zakresie odpowiedzialności konstytucyjnej wobec członka organu kolegialnego (na przykładzie KRRiT), [w:] Postępowanie przed Komisja Odpowiedzialności Konstytucyjnej. Zagadnienia modelowe, Biuro Analiz Sejmowych Kancelarii Sejmu, Warszawa 2007.

- Kmiecik R., W sprawie możliwości wszczęcia postępowania w przedmiocie odpowiedzialności konstytucyjnej członka organu kolegialnego (na przykładzie KRRiT), „Przegląd Sejmowy”, 2008, nr 2.

- Kowalska M., Trybunat Stanu, [w:] Ustrój organów ochrony prawnej, red. B. Szmulik, M. Żmigrodzki, Wydawnictwo UMCS, Lublin 2005.

- Kowalska M., Trybunat Stanu, [w:] Encyklopedia politologii. Instytucje i systemy polityczne, t. II, red. B. Dziemidok-Olszewska, W. Sokół, Wydawnictwo Wolters Kluwer, Warszawa 2012.

- Kręcisz W., Glosa glosy do wyroku Sądu Najwyższego z 6 stycznia 1999 r. (sygn. akt III RN 108/98), „Przegląd Sejmowy”, 1999, nr 4 (33).

- Lis-Starowicz D., Postępowanie w sprawie odpowiedzialności postów i senatorów przed Trybunałem Stanu (uwagi na marginesie art. 107 Konstytucji RP), „Przegląd Sejmowy", 2004, nr 6.

- Mojak R., Parlament a Rzad w ustroju Trzeciej Rzeczypospolitej Polskiej, Wydawnictwo UMCS, Lublin 2007.

- Mojak R., Status ustrojowy Rady Ministrów w nowej Konstytucji Rzeczypospolitej Polskiej (zagadnienia wybrane), [w:] Ustrój polityczny Rzeczypospolitej Polskiej wnowej Konstytucji z 2 kwietnia 1997 roku. XL Ogólnopolska Konferencja Katedr Prawa Konstytucyjnego 4-6 czerwca 1998. Kazimierz Dolny nad Wisła, red. W. Skrzydło, R. Mojak, Wydawnictwo UMCS, Lublin 1998.

- Odrowąż-Sypniewski W., Odpowiedzialność konstytucyjna członków organów kolegialnych, „Przegląd Sejmowy”, 2006, nr 6.

- Odrowąż-Sypniewski W., Odpowiedzialność konstytucyjna członków organów kolegialnych, [w:] Postępowanie przed Komisja Odpowiedzialności Konstytucyjnej. Zagadnienia modelowe, Biuro Analiz Sejmowych Kancelarii Sejmu, Warszawa 2007.

- Patyra S., Prawnoustrojowy status Prezesa Rady Ministrów w świetle Konstytucji z 2 kwietnia 1997 r., Wydawnictwo Sejmowe, Warszawa 2002.

- Pietrzak M., Odpowiedzialność konstytucyjna w Polsce, Wydawnictwo Naukowe PWN, Warszawa 1992.

- Sarnecki P., Kierownicze kompetencje Prezesa Rady Ministrów w strukturze administracji rzadowej, „Przegląd Sejmowy”, 2011, nr 3.

- Sarnecki P., Nota do art. 53, [w:] Komentarz do Konstytucji Rzeczypospolitej Polskiej, t. I, red. l. Garlicki, Wydawnictwo Sejmowe, Warszawa 1995.

- Sarnecki P., Opinia o możliwości wszczęcia postępowania w zakresie odpowiedzialności konstytucyjnej wobec członka organu kolegialnego, [w:] Postępowanie przed Komisja 
Odpowiedzialności Konstytucyjnej. Zagadnienia modelowe, Biuro Analiz Sejmowych Kancelarii Sejmu, Warszawa 2007.

- Sarnecki P., W sprawie możliwości wszczęcia postępowania w przedmiocie odpowiedzialności konstytucyjnej członka organu kolegialnego (na przykładzie KRRiT), „Przegląd Sejmowy”, 2008, nr 2.

- Skrzydło W., Konstytucja Rzeczypospolitej Polskiej. Komentarz, Wydawnictwo Wolters Kluwer, Warszawa 2009.

- Skrzydło W., Rada Ministrów i administracja rzadowa, [w:] Polskie prawo konstytucyjne, red. W. Skrzydło, Wydawnictwo Morpol, Lublin 1998.

- Skrzydło W., Ustrój polityczny RP w świetle Konstytucji z 1997 roku, Wydawnictwo Zakamycze, Kraków 1998.

- Sobczak J., Sądy i trybunaty, [w:] Polskie prawo konstytucyjne, red. W. Skrzydło, Wydawnictwo Verba, Lublin 2003.

- Świda-Łagiewska Z., Zasady odpowiedzialności konstytucyjnej i system kar, [w:] Trybunat Stanu w PRL, Wydawnictwo Książka i Wiedza, Warszawa 1983.

- Uzasadnienie do wyroku Sąu Najwyższego z dnia 6 stycznia 1999 r., [w:] Informacje - Orzecznictwo innych sq̨ów, „Przegląd Sejmowy”, 1999, nr 4.

- Wasilewski A., List do redakcji w sprawie glosy do wyroku Sadu Najwyższego z 6 stycznia 1999 r. (sygn. akt III RN 108/98 - OSNIAPiUS 1999, nr 20, poz. 639) opublikowane w „Przegladzie Sejmowym” z 1999 r., nr 4, „Przegląd Sejmowy”, 2000, nr 2.

- Wiliński P., Wszczęcie postępowania w przedmiocie odpowiedzialności konstytucyjnej członka organu kolegialnego, [w:] Postępowanie przed Komisja Odpowiedzialności Konstytucyjnej. Zagadnienia modelowe, Biuro Analiz Sejmowych Kancelarii Sejmu, Warszawa 2007.

- Winczorek P., Komentarz do Konstytucji Rzeczypospolitej Polskiej z dnia 2 kwietnia 1997 r., Wydawnictwo Liber, Warszawa 2000.

- Wróblewski J., Delikt konstytucyjny, Wydawnictwo Epoka, Warszawa 1985.

- Zaleśny J., Odpowiedzialność konstytucyjna, Praktyka III RP, Oficyna Wydawnicza ASPRA-JR, Warszawa 2004.

- Zgryzek K., Opinia prawna o możliwości wszczęcia postępowania w zakresie odpowiedzialności konstytucyjnej wobec członka organu kolegialnego (na przykładzie KRRiT), [w:] Postępowanie przed Komisją Odpowiedzialności Konstytucyjnej. Zagadnienia modelowe, Biuro Analiz Sejmowych Kancelarii Sejmu, Warszawa 2007.

- Zgryzek K., W sprawie możliwości wszczęcia postępowania w przedmiocie odpowiedzialności konstytucyjnej członka organu kolegialnego (na przykładzie KRRiT), „Przegląd Sejmowy”, 2008, nr 2.

- Zrębiec D., Zakres podmiotowy i przedmiotowy odpowiedzialności konstytucyjnej w nowej Konstytucji RP (wybrane zagadnienia), „Annales Universitatis Mariae Curie-Sklodowska", 1999, sectio G, vol. XLVI. 
Streszczenie: Odpowiedzialność konstytucyjna należy do kanonów rozwiązań konstytucyjnych współczesnych państw demokratycznych. Jedną z jej cech pozostaje osobisty i ograniczony podmiotowo charakter. Wśród podmiotów podległych kognicji Trybunału Stanu, zgodnie z regulacją polskiej konstytucji, znajdują się jednakowoż funkcjonariusze państwa, wchodzący w skład kolegialnych organów państwa. Stąd zasadnym jest postawienie sobie pytań o możliwość pociągnięcia ich do zindywidualizowanej w swej formie odpowiedzialności konstytucyjnej za działania podjęte z naruszeniem prawa przez kolektywny organ państwa, którego z mocy prawa integralną część stanowią, i o przedstawienie zapatrywań przedstawicieli doktryny prawa konstytucyjnego na powyższe zagadnienie.

Słowa kluczowe: Trybunał Stanu, odpowiedzialność konstytucyjna, organ kolegialny, Rada Ministrów, minister

\section{The Collegiality of the Activities of the Council of Ministers and the Constitutional Responsibility of Its Members in the Assessment of Polish Doctrine}

Summary: The Constitutional responsibility is the core of the contemporary state's political systems. One of its features is personal and limited character. Among the entities subjected to the jurisdiction of the State Tribunal according to the Polish Constitution, there are state agents which are part of the collegial state organs. That is why, we can ask the questions, if their individual constitutional responsibility is possible? Is it possible, that they can be brought to account for the actions made by the collective state organs in which they are employed? To answer those questions, we will analyze the research of the authors of the Constitutional Law doctrine.

Keywords: State Tribunal, Constitutional responsibility, collegial organ, the Cabinet, minister 